\title{
Entre a escrita da história e
} a narratividade da história visual: a fotografia

\section{Between the writing of history} and the narrativity of visual culture: photography

Fabrício Antônio Antunes Soares Fátima Moura Ferreira 
Resumo: O texto explora e discute questões e perplexidades do uso crescente da imagem fotográfica no âmbito dos estudos históricos contemporâneos. Neste contexto, dá lugar a uma reflexão sobre as potencialidades do estudo da visualidade entre o universo das práticas historiográficas e o horizonte da escrita da história como narrativa.

Palavras-chave: Escrita da História; Cultura Visual; Narrativa e Fotografia.

Abstract: The text explores and discusses issues and perplexities of the growing use of photographic images in contemporary historical studies. In this context, it gives rise to a reflection on the potential of the study of visuality between the universe of historiographic practices and the horizon of the writing of history as a narrative.

Keywords: The Writing of History; Visual Culture; Narrative and Photography. 


\section{Imagem: rumo a uma história visual}

"The event is not what happens. The event is that which can be narrated"

(FELDMAN, 1991 p. 14)

A imagem é a semelhança ou sinal das coisas. Mas também se pode conservar independentemente das coisas. Ela inicia-se no processo de imaginação, isto é, na possibilidade de evocar ou produzir imagens independentes da presença do objeto a que se reporta. Pela imagem e pela imaginação, o processo de entendimento começa. (KANT, 2005). A criação da imagem implica a existência de sujeitos produtores da imaginação socialmente constituídos. É certo que na produção da imagem entendida como a evocação de algo ausente o sujeito produtor da imagem dispõe de um universo visual anterior ao próprio ato de imaginar. Assim, como observou Bachelard (1978), a imaginação é também o despertar da criação poética. O mesmo é dizer: através da imaginação é possível tanto reproduzir as representações tidas por hegemônicas como criar representações alternativas sobre o real. Assim, a imagem enquanto representificação de algo ausente é passível de revestir uma dimensão criadora e/ou uma dimensão reprodutora de sentido.

Se considerarmos que a fotografia é sempre imagem visual, ela tem que ser interpretada no interior desta perspectiva. É certo que há diferenças técnicas, artísticas, estéticas ou sociais que diferenciam a fotografia da pintura ou de outra fonte iconográfica. (PANOFSKY, 1955; GOMBRICH, 1968). Nela se jogam códigos e tradições particulares e/ou cruzados, como acontece entre as demais materialidades visuais, que obrigam a considerar a singularidade das respectivas linguagens. Neste sentido, a imagem visual é entendida como representação de uma ausência e, historiograficamente, a imagem é tomada como testemunho de um ter-sido passado ou, de outro modo, como expressão narrativa ou traço/ vestígio de um passado.

No decurso do segundo quartel do século XX, a renovação da historiografia preconizou a ampliação do universo documental para além dos registros escritos, através da mobilização das imagens visuais nas suas diferentes materialidades e de outros artefatos ou vestígios. (IGGERS, 2005; BURKE, 2005). Numa época em que o axioma da historiografia se alicerçava no documento fundado na palavra escrita entendido como texto, tal viragem implicou refundar o conceito de documento e de texto. Destarte, todo o vestígio do passado quando questionado 
historiograficamente foi instituído em objeto válido e passível de análise por parte dos historiadores, implicando procedimentos críticos adequados. O que, por outras palavras, equivale a aceitar a singularidade inerente a cada suporte documental, liberto de uma pretensa ordem de valor ou de grandeza, a ser questionado sob o prisma de metodologias plurais e em razão das preocupações e das exigências do programa do investigador.

É certo que as vicissitudes que perpassam o trânsito histórico se retraduzem no campo das práticas historiográficas em resistências e atavismos, em larga medida alimentados pela força da tradição disciplinar. (CERTEAU, 2007; BURKE, 2004; MENESES, 2005, 2012). Estas coexistem no curso do tempo a par da emergência e da afirmação sincopada de novas práticas. Perspectivando o campo da historiografia como campo de lutas (CERTEAU, 2007), importa atender aos impulsos e trânsitos de renovação teórica e metodológica que extravasam em momentos sinalizados como viragens, nomeadamente a linguistic turn, a visual turn. ${ }^{3}$ Assim, vale a pena interrogar esse processo historiográfico numa dupla perspectiva. De um lado, na condição de desafio e de estímulo crítico que a teoria suscita sobre o plano das práticas historiográficas. De outro lado, no impulso de abertura e/ou contra-abertura a novos objetos e problemáticas de estudo. O processo longe de se apresentar linear é atravessado por lógicas de mediação sem força bastante para darem lugar a horizontes de homogeneização do campo historiográfico.

Ao ampliar a pesquisa histórica através do recurso à fotografia, a história visual afirmou-se como categoria que analisa as imagens dentro de uma perspectiva holística, compreendendo a dimensão documental imanente ao material histórico assim como a expressão da visualidade na história ${ }^{4}$. Nestes termos, a imagem visual é percepcionada para além de sua pictorialidade e examinada na condição de rastro do tempo. É assim tomada como dispositivo e como narrativa dotada de uma estética particular, que atua como moldura do modo de olhar/ver os objetos e que conforma modelos de sensibilidade e de comunicação, veiculando representações e modelando interações dos sujeitos históricos com a realidade social - sem, contudo, anular o espectro a experiências singulares. (DUBOIS, 1993). A história visual deve ser assim entendida não como um mero apêndice da história ou um subdomínio da história da arte. ${ }^{5}$ Metodologicamente, a performance da pesquisa em história visual é transdisciplinar, o que potencia o debate em relação à virada icônica ou visual com as demais ciências humanas e sociais.

Em larga medida, este movimento foi impulsionado por amadurecimentos 
múltiplos ocorridos na disciplina histórica que se robusteceram reciprocamente. Por um lado, o salto tecnológico mundial observado no campo das tecnologias de informação foi percepcionado como uma mudança estrutural no universo das práticas historiográficas e das possibilidades de renovação em termos teórico-metodológicos, concretamente potencializando abordagens transversais no âmbito dos estudos de história. (SILVEIRA, 2018). Como decorrência, os historiadores passaram a dispor de oportunidades inteiramente inéditas no acesso a corpora documentais, estimuladas pelas facilidades abertas pela desmaterialização documental. (NOIRET, 2015). Por outro lado, as transformações societais em curso influíram poderosamente nos desafios suscitados pelo império da visualidade, muito em particular entre o segmento de historiadores mais jovens que cresceram sob o impacto das novas mídias. (CÁCERES; GAYOL, 2018). Talvez por isso, o questionamento crescente que se faz sentir em torno da visão logocêntrica do mundo ditada pela aceleração global e tecnológica, vertidas nos fenômenos de mobilidade e de minituarização dos equipamentos (devices), tenha estimulado novas práticas e novos códigos de leitura e de escrita (exemplo, redes sociais), suscetíveis de se retraduzirem em legibilidades novas, ancoradas sobre a hegemonia do visual. Essa mudança de paradigma societal repercute-se a diferentes ritmos, escalas e modalidades no campo da historiografia, justificando, porventura, a quase omnipresença do visual e a valorização (versus vulgarização) que atravessa a utilização de fontes visuais. (STANLEY, 2009).

Um dos efeitos deste amadurecimento historiográfico traduz-se na atenção crescente que a história visual desperta entre a investigação e a comunidade de historiadores. Um outro reflete-se no estímulo à reflexão alargada em termos metodológicos. No seu conjunto, estes elementos contribuem para relevar as potencialidades heurísticas que resultam de uma articulação mais densa e equilibrada entre materiais documentais, tendo presente o horizonte das preocupações historiográficas e os respectivos cruzamentos teóricometodológicos. (MONTEIRO, 2006 e 2008).

Contudo, apesar dos avanços observados, a imagem permanece ainda como uma ponte para um outro domínio ou, na melhor das hipóteses, atua como uma espécie de estímulo ou ponto de partida para investigações centradas em fontes históricas tidas por mais "sérias". Nesta perspectiva, importa examinar de que modo os historiadores preferem ou não as imagens como fontes históricas e as trabalham em termos de conteúdo, sem negligenciar a componente estética que eventualmente revestem. Dito em termos mais simples, interessa-nos 
examinar qual o papel narrativo que lhes é ou não imputado. ${ }^{6}$ Apesar de muitos investigadores reconhecerem o papel narrativo das imagens, de toda maneira não se encontra suficientemente esclarecido o modo de garantir a importância epistemológica das imagens visuais (e da fotografia, em particular) no interior da estrutura de efetivação cognitiva do passado. Desse modo, é nosso objetivo problematizar a dimensão cognitiva e semiótica da fotografia enquanto espaço de possibilidade de narrar o passado. Isso significa admitir que, para além do espaço de reprodução do passado, as imagens visuais estão longe de refletirem passivamente o passado, atuando na própria história.

\section{Imagem fotográfica: a emergência de novas gramáticas visuais}

Tendo subjacente a trajetória técnica e o movimento de disseminação da fotografia no curso do Oitocentos, o foco da reflexão centra-se no impacto da imagem fotográfica nos modos de dar a ver e de representar o mundo. O mesmo é dizer: as possibilidades abertas de materializar, através da imagem, valores e ideias, fatos e sentidos da realidade que desaguam em representações do mundo, enunciadas numa perspectiva (dominantemente) hegemônica.

Desde os seus primórdios, a imagem fotográfica plasmou um potencial de reprodução da realidade concomitante ao potencial de revelação do real. (KRACAUER, 2013). Ambas as faculdades influíram na corporização de uma matriz de objetividade ilusória, aparentemente sem filtro, contaminando as percepções e as representações do mundo. Porventura, a autoridade da imagem fotográfica entendida como sinônimo de realidade - isto é, como a expressão mais fina do que (supostamente) é ou foi ou aconteceu, mediante a captação e o registro de um momento, de um acontecimento, de uma paisagem, num presente temporalmente datado, cristalizado na prova fotográfica - constitui uma espécie de reverso e de prolongamento do império da ciência e da técnica, vertidos nos ideários positivistas e expressões realistas que moldaram a modernidade.

Em breve, o valor do enunciado material da imagem fotográfica sobrepôs-se aos constrangimentos ditados pela técnica, desembocando na retradução da experiência e visão do mundo a preto e branco, expressão imanente da fotografia nos seus primórdios. Em paralelo, foi-se constituindo um corpus temático privilegiado - composto por uma plêiade de objetos: retratos, paisagens, ambientes -, investido das regras de encenação do mundo, nas componentes física e humana. Pouco depois, os limites desse corpus diluíram-se, abarcando 
as fronteiras do mundo - incluindo a possibilidade de conter a deturpação intencional do real (e já não meramente técnica), sob o prisma da fotografia como artefato artístico ou artefato propagandístico (fotomontagem).

Neste curso temporal, o sistema de linguagem da fotografia foi sendo fixado dando lugar à emergência de uma nova gramática visual emprestada das relações complexas e sinuosas entretecidas com o universo da arte, em particular da pintura. Deixando de lado essa tensão simbiótica fundadora, atravessada pelo debate classificatório entre arte e técnica (BENJAMIN, 2006a), importa reter a emergência de um novo campo visual investido de um poder de reprodutibilidade e de disseminação desconhecidos que influiriam, a seu modo, no processo de reconfiguração dos dispositivos comunicacionais das sociedades modernas. (BENJAMIN, 2006b). Muito em particular, deu azo à criação de imaginários visuais alternativos em consonância com as tessituras ideológicas que pautavam a marcha da modernidade. O potencial da imagem fotográfica ampliou-se então pela faculdade acrescida de não só registrar, expressar, revelar, narrar, comunicar os sucessivos presentes, mas igualmente de projetar, materializando horizontes de futuro entendidos como marcadores ideológicos dos projetos sociais que se confrontavam à escala mundial. (KOSELLECK, 2004).

Há, porém, que não confundir a simultaneidade (ainda que relativa) que preside ao ato de produção e ao ato de recepção da imagem fotográfica num presente coevo, relativamente à operação de observação da fotografia, num presente temporalmente distanciado do registro de outrora. Deixando de lado, por razões de economia de argumento, as interpretações e os sentidos potenciais associados às teorias da recepção, importa avançar com leituras potenciais oferecidas pela fotografia do passado.

A este propósito, pondere-se a seguinte passagem de Sontag (1986, p. 14, grifo nosso), acolhendo o elevado poder de interpelação hermenêutica que encerra na trama deste texto:

A fotografia implica que conhecemos o mundo se o aceitarmos como a câmara o regista. Mas isto é o oposto da compreensão. Toda a capacidade de compreensão está enraizada na capacidade de dizer não. Em rigor, nunca se pode compreender nada a partir de uma fotografia. É claro que as fotografias preenchem vazios nas nossas imagens mentais do presente e do passado, por exemplo as imagens de Jacob Riis da miséria e sordidez de Nova Iorque na década de 80 do século passado são particularmente instrutivas para os que desconhecem como era 'dickensiana' a 
pobreza urbana da América no final do século XIX. No entanto, a maneira como a câmara apresenta a realidade esconde mais do que revela. Como Brecht observou, uma fotografia das fábricas Krupp não revela praticamente nada sobre essa organização. Em contraste com a relação amorosa, que é baseada na aparência, a compreensão é baseada no modo como as coisas funcionam. Só o narrativo nos permite compreender.

Mais do que recensear eventuais motivações, necessariamente plurais, que presidem ao ato de observar, ver, olhar fotografias do passado, o excerto acima obriga-nos a recolocar, num primeiro momento, a questão dos usos e dos sentidos sociais da fotografia do passado. Além do deleite, da rememoração (eventual) de um passado ou de uma memória pessoal ativados pela imagem, do seu potencial valor informativo, emocional, estético, afetivo ou outro, para que servem as imagens fotográficas do passado?

Numa perspectiva acadêmica, as abordagens multidisciplinares que a fotografia histórica e contemporânea suscita e possibilita são emblemáticas do seu elevado significado enquanto campo aberto a interpretações e estudos sobre categorias relativas ao humano. Entre a faculdade imensa da imagem devolver impressões, fragmentos, traços do real humanizado, objeto de interpelação várias, a abordagem do historiador apresenta algumas singularidades.

Porventura, a dimensão menos significativa que importa equacionar diz respeito ao estatuto que a imagem fotográfica entretece com a suposta verdade ou realidade. $\mathrm{Na}$ perspectiva do historiador atento e familiarizado com fontes iconográficas, o ato de observar, analisar e interpretar a imagem fotográfica implica o confronto entre a tensão, manifesta ou latente, que subjaz ao enunciado visual, isto é, entre aquilo que a imagem mostra ou representifica e aquilo que a imagem omite, branqueia ou denega - considerando as motivações intencionais ou não que presidem à captação do registro. O investigador é, assim, compelido a descortinar as camadas de significado e de sentido que a imagem corporiza. É levado, consciente ou inconscientemente, a ativar, por um lado, os códigos e as convenções técnico-artísticas, políticas, sociais e culturais que a imagem convoca. Por outro lado, a atender ao enunciado figurativo que a imagem presentifica, sob o espectro das aspirações e preocupações do tempo (da imagem e do investigador). Dir-se-ia assim, na esteira da abordagem de Panofsky (1955), que o investigador opera mediante a descodificação progressiva e sucessiva dos estratos da imagem, decompondo a componente 
descritiva-analítica (iconográfica) da componente interpretativa (iconológica), mobilizando, para o efeito, o legado ideológico, cultural, artístico e técnico que enforma a tradição do campo visual (fotográfico), na dupla perspectiva da produção e da recepção. (PANOFSKY, 1955). A operação analítica descrita pressupõe, em todo o caso, uma leitura holística da imagem entendida como um todo, isto é, como um outro superior ou diferente, não subsumido à soma das suas parcelas ou partes. Metodologicamente, a operação corresponde a uma espécie de deslocação faseada e intercruzada entre as componentes denotativa e conotativa, e a imagem vista como um todo, operação suscetível de ser traduzida na imagem do movimento do vai e vem.

Das linhas expostas, a asserção de Sontag, atrás citada, “em rigor, nunca se pode compreender nada a partir de uma fotografia”, ganha uma outra legibilidade e remete-nos para um segundo plano ou momento de inquirição.

Compreender, na perspectiva da pensadora, implica narrar, isto é, inscrever a imagem nas camadas de significação históricas corporizadas no enunciado visual e que lhe dão sentido. A operação implica, pois, a assunção de uma totalidade que está para além do mero ato de olhar, observar ou sentir - numa espécie de nível zero da visão.

Neste horizonte, aos olhos do investigador a fotografia consuma sempre a materialização ideológica do real. (TAGG, 2013). Certamente fragmentária, mas não por isso menos significativa. Em compensação, faz-se acompanhar, algumas vezes, por sinais ou indícios de revelação, iluminando e abrindo outras frentes ou ângulos de penetração e de compreensão da realidade - nomeadamente, quando a imagem plasticamente evoca "uma formação compósita” (DIDIHUBERMAN, 2017, p. 45) dos estratos do tempo, assim, isso significa ver em cada presente as dimensões temporais do futuro e do passado postas em relação (KOSELLECK, 2004), o que obriga a questionar os limites usuais das delimitações cronológicas ou a concepção de linearidade cronológica e a aceitar trabalhar historicamente a ideia de porosidade cultural entre os estratos do tempo.

Seja como for, a abordagem do historiador encontra-se impregnada por um olhar singular, densificado pela relação privilegiada que entretece com o tempo-espaço históricos e que o habilitam a produzir "uma visão mais distanciada, uma perspectiva mais deslocada no tempo, uma distância crítica”. (GINZBURG, 2014, p. 100). Dito por outras palavras, no ato de observação ou de leitura de uma imagem fotográfica, o historiador convoca, cruza e intercepta, explícita ou implicitamente, um feixe de estratos documentais que influem no 
aprimoramento analítico e interpretativo da imagem. Procedimento análogo se observa quando perscruta linhas de filiação da imagem nos planos da composição figurativa e/ou representacional, convocando códigos e tradições pictóricas ou visuais que lhe garantem um deciframento das mensagens subliminares ao artefato visual, incluindo a possibilidade de dialogar abertamente com o tempo e os seus estratos.

\section{A narratividade da historiografia e os substratos de significação e de sentido}

No primeiro tomo de Tempo e narrativa, Ricoeur (1995) apresenta o argumento de que a narrativa, na disciplina da história, teve sua época de eclipse a partir da primeira geração dos Annales e do modelo nomológico ou covering law de Carl Hempel. O pensador diagnosticou, por seu turno, o regresso da narrativa em termos de explicação histórica a partir das teses narrativistas, de meados do século XX, nomeadamente dos filósofos da história anglo-americanos, como William Dray, George von Wright, Arthur Danto, W.B. Gallie, Louis Mink e, logo após, dos historiadores Hayden White e Paul Veyne.

Como é sabido, as teses narrativistas na historiografia abriram espaço a questionamentos vários sobre o estatuto de cientificidade da história (categoria herdada do século XIX), a relação da historiografia com o discurso literário, nomeadamente no que toca ao papel da retórica na modelação do estilo do historiador, ao lugar da imaginação e da ficção na escrita da história, e, por fim, à relação da historiografia com a cultura visual e a narratividade da imagem. (MALERBA, 2016 e 2018). A compreensão dessa transformação epistemológica no campo da escrita da história contribuiu para perspectivar a relação do historiador com a imagem visual, questão que no texto presente é equacionada através da análise das potencialidades da imagem fotográfica enquanto fonte histórica e enquanto narrativa do passado.

Vale a pena atender a alguns dos desenvolvimentos teóricos em torno do retorno da narrativa. Assim, em 1979, no artigo O retorno da narrativa, o historiador inglês Lawrence Stone sinalizava essa mudança que atravessava a historiografia. Na sua perspectiva, os historiadores sempre contaram histórias, mas como argumentou então:

Nos últimos cinquenta anos, contudo, a função de contar histórias ganhou péssima reputação entre os que se consideravam na 
vanguarda do ofício [...] Agora, contudo, percebo as evidências de uma corrente que anda atraindo muitos 'novos historiadores' proeminentes de volta a um certo tipo de narrativa. (STONE, 2013, p. 9).

Stone (2013) esclarece ainda o significado que imputava ao retorno da narrativa na história. Defendeu que "nenhum historiador narrativo, como os tenho definido, evita a análise, mas esta não constitui o esqueleto em torno do qual seus trabalhos se fazem. [Com efeito] eles estão profundamente preocupados com os aspectos retóricos de sua representação". (STONE, 2013, p. 10). Nesta ordem de ideias, o historiador britânico evidenciou uma deslocação em termos de conteúdo, método e de estilo historiográfico, entre um círculo modesto de historiadores, particularmente relevante no respectivo campo disciplinar. Vaticinou ainda o fim da era da história estrutural e analítica nascida por volta da década de $1930 .^{8}$

Por seu turno, Hartog (2011), analisando esse movimento teórico na historiografia a partir de França, observou que ao longo do século XX se registrou uma disputa em torno da narrativa. Retomando a argumentação que L. Febvre dirigiu à história narrativa, ou melhor dizendo "historizante" subordinada aos eventos e à história batalha, na década de 1930 , Hartog interpretou a rejeição dos Annales em relação à narrativa com base em três pressupostos. Primeiro, em termos de uma querela focalizada no combate à escola metódica dominante no período; segundo, no esforço de anular o que caracterizaria a escola metódica entendida como história narrativa, vassala dos acontecimentos, e que desaguou no entendimento destas como sinônimos; por último, na crítica que os annalistas dirigiam à história narrativa (metódica) perante a centralidade atribuída aos indivíduos e aos acontecimentos, em contracorrente aos fundamentos do projeto epistêmico dos Annales. Com efeito, este projeto assentava na valorização do social como objeto privilegiado e não mais os indivíduos e no elogio da série e do repetitivo ao invés do acontecimento, na esteira da sociologia durkheimiana. Seja como for, segundo Hartog (2011), os Annales nunca questionaram a narrativa em si. Antes ter-se-á caído numa lógica empobrecida segundo a qual renunciar ao narrativo seria renunciar ao acontecimento e ao indivíduo. Por conseguinte, de acordo com o autor que vimos seguindo, não haveria nos Annales uma problematização propriamente dita sobre a narrativa enquanto explicação do passado. Ora, se defendermos aqui o estatuto narrativo da historiografia, o que os Annales terão 
provocado e realizado não terá sido um abdicar estrito da narrativa, mas antes uma reconfiguração de narrativa vinculada à concepção dos metódicos.

Deste modo, passando pelo (re)surgimento do problema da narrativa (Stone), pela avaliação do que é o problema da narrativa (Hartog), o ponto que julgamos importante analisar no âmbito da problemática do presente texto é avaliar o lugar da narrativa na teoria da história contemporânea.

Para White (2011), a narrativa foi e é objeto de intenso debate. Na perspectiva do historiador norte-americano, apesar de a narrativa ser universal e natural, tais características levaram a que a narrativa tenha sido percepcionada com suspeita entre áreas disciplinares que almejavam o estatuto de cientificidade. Desse modo, assistiu-se a um afastamento progressivo em relação à narrativa como modelo de explicação. O retorno da narrativa suscitou, assim, intensos debates, em particular na história. Seguindo White (2011), expressões desse debate refletiram-se nas tomadas de posição daqueles que defendiam que a narrativa carecia de dimensão teórica ou que era alheia a preocupações metodológicas, desaguando num mero discurso com ou sem validade em termos de representação historiográfica. As últimas décadas têm oferecido, porém, reflexões mais consistentes e complexas sobre o tema da narrativa na historiografia. Nesta linha, White (2011) sistematiza cinco abordagens relativas a esta questão.

A primeira abordagem seria representada pelos filósofos analíticos de tradição anglo-americana. ${ }^{10}$ Estes buscaram definir o status epistemológico da narratividade, numa perspectiva global, apresentando-o como um modelo de explicação adequado e válido em relação à história. Numa segunda abordagem estariam os historiadores sociocientíficos, entre os quais se destacam os historiadores dos Annales, designadamente Fernand Braudel, François Furet, Jacques Le Goff e Emmanuel Le Roy Ladurie. Assim, para os representantes desta corrente, a narrativa seria entendida como um estratagema representacional não científico, análogo à ideologia, o que exigiria a sua irradicação de forma a permitir o estatuto de cientificidade da disciplina. Num terceiro grupo, White (2011) recenseou filósofos e teóricos da literatura, nomeadamente Roland Barthes, Michel Foucault, Jacques Derrida, Tzvetan Todorov, Julia Kristeva, Émile Benveniste, Gérard Genette e Umberto Eco. Seguindo White (2011), estes intelectuais examinaram a narrativa nas suas diversas manifestações e consideraram-na semelhante a um "código discursivo", concluindo que esta não correspondia necessariamente à única forma adequada de representação da história. White (2011) menciona ainda os filósofos de orientação hermenêutica, 
tais como Hans-Georg Gadamer e Paul Ricoeur, que constituiriam uma quarta abordagem. Estes relevaram a narrativa em termos de aparição no discurso de uma consciência temporal singular. Por fim, White (2011) recenseia o conjunto de historiadores que não participando de qualquer corrente filosófica, analisam a narrativa do "ponto de vista comum" da profissão, entendendo-a como uma prática artesanal e que classifica como representantes de uma postura eclética em termos de produção historiográfica.

Das linhas expostas, e articulando as explanações de Stone e de White, é lícito concluir-se que a narrativa faz parte da reflexão e das preocupações dos historiadores pertencentes aos mais variados matizes teóricos.

Identificado o ressurgimento da narrativa e após uma análise breve sobre o debate que esta tem suscitado, cremos ser importante definir alguns critérios sobre a relação da história com a narrativa.

Quando narram, os historiadores asserem (no presente) o que é o passado. A narrativa, composta de uma intriga, relata a trajetória de personagens em uma estória (story), em que a partir da evidência e de sinais dispersos faz, narrativamente, surgir a convergência, isto é, a coerência de sentido dos fatos passados (narrado). (RICOEUR, 1995). Os fatos, documentos e evidências que estão “soltos" adquirem sentido na escrita da narrativa. Dito por outras palavras: um sentido é estabelecido para os fenômenos (do passado) que aparecem dispersos fenomenologicamente (no presente). O texto, mais especificamente o mundo do texto ${ }^{11}$ que a narrativa cria, é o lugar de sentido do passado construído pela operação historiográfica. Um fato acontece e, de tal modo, narrativas sobre este fato vão sendo criadas, no curso do tempo, com o fim de dar sentido e controlar/criar a significação sobre este acontecimento passado. Textos são escritos para dar conta do passado e reapresentá-lo novamente no presente. Desse modo, conforme escreve Rüsen (2001, p. 149):

O pensamento histórico, em todas as suas formas e versões, está condicionado por um determinado procedimento mental de o homem interpretar a si mesmo e a seu mundo: a narrativa de uma história. Narrar é uma prática cultural de interpretação do tempo, antropologicamente universal. A plenitude do passado cujo tornar-se se deve a uma atividade intelectual a que chamamos de "história" pode ser caracterizada, categorialmente, como narrativa. A "história" como passado tornado presente assume, por princípio, a forma de uma narrativa. O pensamento histórico 
obedece, pois, igualmente por princípio, à lógica da narrativa. Essa tese é tratada, na teoria da história, como o paradigma narrativista.

Deste modo, o paradigma narrativista da história, seguindo Rüsen, não pretende eclipsar a racionalidade metódica (pesquisa histórica, métodos de investigação), presente desde o século XIX e consagrada na operação historiográfica. O que Rüsen (2001) pretende é demonstrar a complexidade do paradigma narrativista que associado com a racionalidade metódica produzem a potencialização do sentido histórico, nomeadamente em termos de dimensões estética e política. Assim, desenvolve o argumento de que a racionalidade própria da historiografia é a racionalidade narrativa, pois esta repousa sobre a especificidade do pensamento histórico. ${ }^{12}$ Contudo, nem toda a narrativa é histórica, pois para uma narrativa ser histórica ela deve interpretar o passado, isto é:

\begin{abstract}
A especificidade da narrativa histórica está em que os acontecimentos articulados narrativamente são considerados como tendo ocorrido realmente no passado. Além disso, sua coesão interna é concebida como uma representação da evolução temporal vinculada à experiência e como significativa para o auto-entedimento e para a orientação dos sujeitos dos narradores. Com ela, os processos temporais atuais da vida prática dos narradores podem ser entendidos. Para a narrativa histórica é decisivo, por conseguinte, que sua constituição de sentido se vincule a experiência do tempo de maneira que o passado possa tornar-se presente no quadro cultural de orientação da vida prática contemporânea. Ao tornar-se presente o passado adquire o estatuto de 'história'. (RÜSEN, 2001, p. 155).
\end{abstract}

Portanto, seguindo Rüsen (2001), a constituição de sentido operado pela narrativa da história realiza-se de acordo com quatro níveis, a saber: a) percepção da contingência; b) interpretação; c) orientação da vida prática; e d) motivação do agir. Assim sendo, a constituição histórica de sentido pela narrativa atravessa todas as dimensões, desde as mais distintas expressões do cotidiano humano (não limitadas ao texto historiográfico), mas passando ainda pela celebração cívica, pelo discurso congratulatório, o trauma ou o recalque ou eventualmente pela imagem.

Portanto, dentro da argumentação de Rüsen (2001), abre-se um espaço 
para pensar o sentido histórico a partir da narrativa. Contudo, para além da historiografia, o sentido histórico pode encontrar-se em outros modos e formas de expressão narrativa. Assim, uma narrativa processa-se, por um lado, na comunicação cotidiana, tanto no plano da memória como em fragmentos de história ou nas referências a símbolos. Mas, por outro lado, o sentido (do passado) só se manifesta na narrativa. Assim, há um potencial amplo e variado no modo de configurar e fazer presente o passado por meio de uma narrativa. Contudo, esses vários modos de fazer presente o passado têm de preencher as condições para que a narrativa seja qualificada como histórica. Com esse fim, Rüsen (2001, p. 160) sugere recorrer a situações arquetípicas de comunicação na construção da narrativa histórica, pois, como explicita:

Com esse arquétipo pode-se estipular com mais exatidão em que sentido, símbolos, imagens, palavras isoladas, alusões e semelhantes podem ser considerados 'históricos'. Eles são 'históricos' se e quando o sentido que possuem nas situações de comunicação da vida prática emerja plenamente na forma de uma história na qual o passado é interpretado, o presente entendido e o futuro esperado mediante essa mesma interpretação.

Diríamos que a narrativa pressupõe explícita ou implicitamente a mobilização da interpretação e da teoria em camadas de intensidade variável, segundo o perfil do historiador. Pois não há apenas uma história, mas narrativas que se ancoram em substratos de significação e de sentido e que obrigam a descortinar as lógicas de construção e de representação do social. Desse modo, articulando o paradigma narrativista com o objetivo do artigo, problematiza-se qual é o papel da fotografia numa narrativa historiográfica, isto é, se a imagem fotográfica é apenas fonte histórica ou pode ser entendida analogamente como uma forma de narrativa para o historiador. Dito de outro modo, é possível o historiador narrar através de imagens ou estas só podem ser entendidas como fontes históricas ou meros complementos da narrativa textual?

\section{A interseção entre o visual e o narrativo verbal e as frações da história}

Mas regressemos à imagem e à sua polimorfia ditada pelas práticas plurais e os usos sociais da fotografia, em particular a partir das décadas finais do século XIX. É certo que à imagem fotográfica são vinculados estatutos de 
autoridade desiguais segundo a entidade responsável pela produção/autoria da imagem. (TAGG, 1988). Os diferentes estatutos de autoridade plasmam-se nas modalidades de registro oficial, público ou privado e consequentes hierarquias de valor conferidas à imagem, balizadas entre o testemunho (entendido como prova ou indício de verdade) e o traço ou mero vestígio de inscrição, mais ou menos anônimo. Atente-se na primeira situação: a imagem fotográfica entendida como testemunho.

É sabido que os usos estatais e os usos da imprensa ditaram e consagraram em larga medida a marca de autenticidade ou de verdade reputada à imagem visual. No primeiro caso, a generalização progressiva das práticas e das modalidades de registro fotográfico entre as agências oficiais potenciaram os dispositivos de controle, vigilância e de regulação sociais. Estas, ancoradas nos benefícios proporcionados pela mobilização e agenciamento de saberes (geografia, história, antropologia, medicina, disciplinas coloniais, estatística, economia, etc.) e nos impactos gerados pela reatualização ou criação de organismos estatais, suscitaram possibilidades novas no plano da interação entre os mecanismos do poder. Limitando-nos a algumas ilustrações exemplares, disso são exemplo as práticas de recenseamento dos indivíduos (motivadas por finalidades de governo da violência ou de controle e gestão do movimento das populações) ou os usos coloniais da fotografia que exponenciaram as vantagens auferidas pela díade saber-poder. Em pouco tempo, os usos da fotografia estenderamse aos demais campos da governação, facultando a produção de inventários minuciosos sobre o impacto das políticas econômicas e sociais estatais e os seus desígnios sociopolíticos (por exemplo, Walker Evans e Dorothea Lange, Farm Security Administration), no horizonte dos dispositivos de territorialização e de afirmação do aparelho estatal, suportados pelo agenciamento de estratégias comunicacionais sofisticadas. (MOSSE, 1975; HERF, 1984; TAGG, 1988; RIBALTA, 2010, entre outros).

No segundo caso, entre a imprensa, a vulgarização da imagem fotográfica influiu, por seu turno, no quadro da massificação das visões e das representações do mundo, crescentemente hegemônicas. Desde cedo, o potencial impositivo da imagem ampliou-se pela faculdade de orientar o olhar do leitor, através de manchetes e de legendas, de forma a incutir o sentido e o significado precisos a reter, apoiada nos recursos proporcionados pela modernização das artes gráficas e suas irradiações, disseminadas através de referentes modelares. Destarte, foi-se enraizando (isto é, incorporando) o valor instrumental da imagem fotográfica como sinônimo de realidade, de memória e de arquivo do 
mundo, numa espécie de mescla interconectada entre as diferentes espécies da imagem - gráfica, ótica, perceptual, mental e verbal. (MITCHELL, 2009).

À maneira de um caleidoscópio, o historiador passou a dispor de um leque alargado de possibilidades de abordagem e de análise, de acordo com o potencial e a singularidade do corpus de imagens visuais em estudo. Em função do programa de investigação e do horizonte (sub)disciplinar, o foco da análise tanto poderá incidir sobre a análise privilegiada da componente documental e/ ou de outra componente, nomeadamente através da fixação de prioridades que norteiam o estudo do enunciado visual entendido como malha polissêmica, independentemente da intencionalidade que preside ao registro, e bem assim de outra qualquer componente ditada pela criatividade do investigador.

Parafraseando Tagg (2013) - a propósito da análise de duas imagens fotográficas de temáticas afins, que repousam numa "mesma estrutura ideológica aparentemente sem fissuras chamada lar" e que corporizam, nas suas diferenças e nas suas semelhanças, “os conceitos de família e lar” -, importa sobretudo atender "ao duplo movimento que tipifica o discurso ideológico" gerador, em larga medida, da percepção redundante que permeia a observação de fotografias antigas. Vale a pena reproduzir as suas palavras pela explicitação magistral que estas oferecem a respeito do duplo movimento que encobre o discurso ideológico, no plano do registro fotográfico:

Importa, pois, considerar por um lado, a construção ideológica posta nos objetos e acontecimentos [que] concretiza um esquema mítico geral ao incorporá-lo na realidade desses momentos específicos. Porém, ao mesmo tempo, a própria conjuntura dos objetos e acontecimentos e o esquema mítico desistoriza os mesmos objetos e acontecimentos, deslocando a conexão ideológica para o nível arquetípico do natural e universal, de modo a esconder a sua natureza especificamente ideológica. $\mathrm{O}$ que o esquema mítico ganha em concretude é contrabalançado por uma perda de especificidade histórica por parte dos objetos e acontecimentos. (TAGG, 2013, p. 360)grifos no original.

Porventura, a apreensão desse esquema mítico consigna, algumas vezes, uma das expressões mais exemplares da relação dialógica entre tempos, numa espécie de fluir subterrâneo da experiência humana. Quase como se espaço e tempo se entrelaçassem, desaguando na aparência (pois ideológica) do enunciado de universalidade e de intemporalidade. 
Aqui chegados, somos levados a admitir que a arte do fotógrafo se ergue como condição necessariamente singular do registro. Sem descurar esse atributo particular que se retraduz na consagração da autoria, isto é, do artista, acontece, por vezes, que o historiador é surpreendido pela qualidade do registro visual captado por um fotógrafo amador ou semiprofissional, de acordo com os parâmetros que pautam o respectivo itinerário formativo em termos técnicos ou profissionais. Essa qualidade é reveladora de uma força imagética apenas esperada entre aqueles que são nomeados e classificados como artistas. Plausivelmente, motivos vários contribuem para explicar essa situação um tanto ou quanto paradoxal, sem contudo serem suscetíveis de fornecerem a chave plena desse enigma.
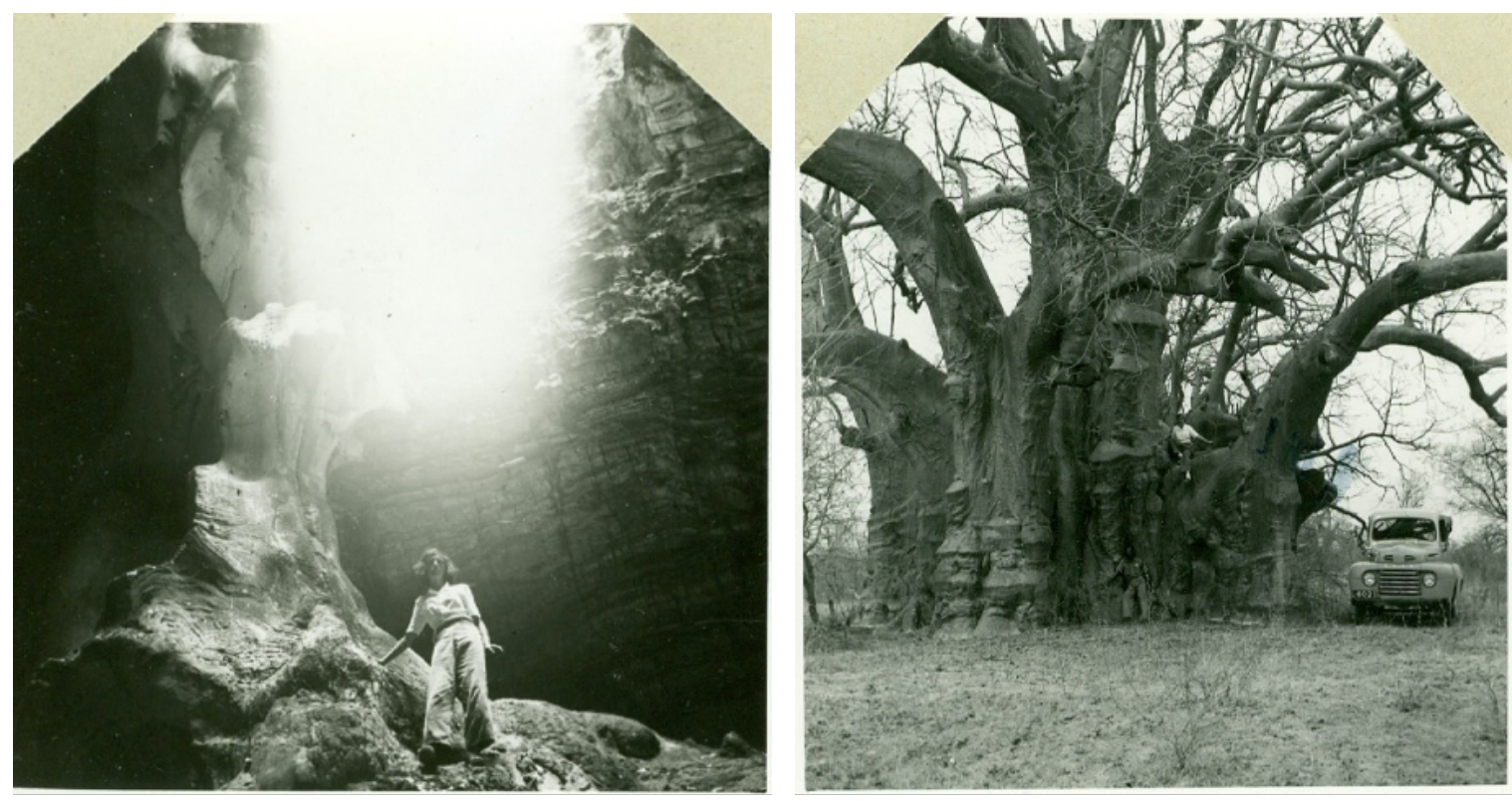

Ao olhar do observador, as figuras 1 e $2^{15}$ dispostas em plano contíguo são suscetíveis de desencadearem um feixe de reminiscências múltiplas: sensoriais, estéticas, temporais, espaciais, inclusive históricas. O poder de evocação transcende a imagem presentificada, considerando, a título de hipótese, o espanto humano face à natureza e o desejo de o registrar, guardar, numa espécie de eternização oposta à efemeridade da memória humana ou à inevitabilidade da morte. Dificilmente, o olhar do historiador não se deterá, ainda que por frações de segundo, no potencial imagético que emana das figuras. Provavelmente, num segundo momento, será levado a reposicionar o seu olhar de acordo com as premissas e as preocupações do seu programa de investigação, interagindo ou não com outras oportunidades de enfoque do seu 
programa de estudo. Em qualquer dos casos, o historiador confronta-se sempre com a singularidade da fonte iconográfica vertida no poder da visualidade, forçosamente distinto do poder do dizível. Ambos, porém, não deixam de se debater necessariamente com o poder da palavra, equacionado como elemento magistral de elocução no interior de uma composição narrativa que dialoga, ainda que sub-repticiamente ou veladamente, com a presentificação figurada (ou não) da imagem.

Das linhas expostas, afiguram-se poderosas as oportunidades hermenêuticas abertas à historiografia pela interseção entre o visual e o narrativo verbal, no sentido de densificar o que é contado ou narrado, seja a partir de uma simples imagem ou de uma série de imagens pertencentes a uma mesma coleção ou núcleo documental.

Há exemplos magistrais de estudos que partindo da exploração densa e fina de uma fonte iconográfica dão a ver as camadas de sentido e de interpretação extrapoladas a partir de um horizonte de análise simultaneamente dialógico e dialético. Dir-se-ia que estamos perante exemplares de erudição distintiva, obra de investigadores maiores, dotados de uma mestria paradigmática, suscetíveis de operarem não a partir da linearidade do tempo cronológico, equacionado como referente, mas antes através das afinidades eletivas que anteveem entre figurações visuais e pictóricas pertencentes a diferentes épocas históricas. Em suma, dotados de um talento invulgar no modo como conceitualizam e dialogam com o tempo, os seus estratos e os seus movimentos, libertos da rigidez arquetípica que regula a tradição do campo disciplinar. Perante essas obras, suportadas pela montagem de uma narrativa singular, porventura não passível de ser enquadrada numa moldura disciplinar específica, assente em fronteiras rígidas, apreende-se um filão cintilante que se configura, a todos os títulos, original.

Outras são, porém, as oportunidades abertas por investigações centradas no estudo de grandes massas documentais, disponibilizadas por coleções de imagens de grande dimensão, sejam elas estatais, públicas ou privadas e que se estendem no tempo.

Sem pretender esgotar as hipóteses múltiplas de estudo, importará apenas mencionar as possibilidades abertas pela desconstrução crítica das categorias classificatórias pré-existentes, mediante a intercepção cruzada de metodologias quantitativas e qualitativas. Limitemo-nos a avançar com uma proposta de problematização e de análise centrada nas modalidades de inscrição do tempo cronológico no plano das representações e representificações das temáticas 
recenseadas.

Também aqui é exigido um questionamento dialógico e dialético das imagens que permita apreender indícios de mutação nos objetos representificados sob a aparente permanência (ou não) das práticas de registro fotográfico - norma geral mais resiliente à mudança ainda que sujeita à pressão das circunstâncias que atravessam as conjunturas político-ideológicas, a diferentes escalas.

A análise fina das imagens (auxiliada por uma seleção criteriosa do universo da pesquisa em termos de construção de uma amostra significativa) permitirá densificar o estudo sobre o que é registrado e como é registrado, diagnosticar as motivações e as tradições que modelam o enunciado visual através da linearidade do tempo interceptado pelos estratos do tempo, permitindo avançar para além do mero confronto entre a intencionalidade do registrado/mostrado e do omitido ou pretensamente denegado - sem esquecer, como ponto prévio, a exigência de explorar o que é presentificado para além da suposta linearidade em que assenta a (análise da) intencionalidade do registro e da conservação da imagem.

Das linhas expostas, depreende-se a ampliação dos horizontes que se abrem ao estudo da visualidade, suscetível de originar itinerários narrativos visuais alternativos aos das narrativas escritas que tomam a imagem por fonte histórica. Alternativos, distintos ou complementares, estes itinerários encerram modalidades de conhecer e dar a ver o mundo, nas especificidades das respectivas linguagens e gramáticas.

\section{Considerações finais}

Partindo da problemática da história como narrativa, o texto examina questões relacionadas com os usos crescentes da imagem visual (fotografia) no âmbito dos estudos históricos contemporâneos, no quadro dos desenvolvimentos observados na história visual.

Revisitam-se, neste contexto, temas caros da reflexão sobre a imagem e os usos sociais e históricos da fotografia, ao mesmo tempo que se discutem razões que justificam a crescente onipresença do visual entre os estudos históricos mais recentes. Em concreto, examinam-se tensões e resistências que se colocam ao uso da imagem visual como fonte histórica, questionamento que se prolonga à problematização da imagem visual como dispositivo narrativo. Neste sentido, releva-se, em particular, a emergência de novas gramáticas visuais despoletadas pelos usos massivos da fotografia nos contextos estatais e nos 
universos da imprensa escrita e que obrigam a problematizar as intercepções plurais entre o visível e o dizível, no campo da produção historiográfica. Atenção particular é reservada às dimensões metodológicas que atravessam o campo dos estudos visuais. Em simultâneo, avançam-se com algumas propostas teórico-metodológicas que mostram as potencialidades hermenêuticas abertas pelos estudos da visualidade e que evidenciam a força narrativa e generativa da fotografia e que possibilitam o alargamento da investigação histórica atenta ao ato e efeito multiplicador da fotografia enquanto reflexo e criação sobre e da realidade histórica.

O texto conclui, em suma, sobre as singularidades que dão formas às linguagens - visual e escrita - que se oferecem ao conhecimento e à visão do mundo (e da história em particular), necessariamente não redutíveis.

\section{Referências}

BACHELARD, Gaston. A poética do espaço. São Paulo: Abril Cultural, 1978. (Os Pensadores).

BELTING, Hans. Faces. Une Histoire du visage. Paris: Gallimard, 2017.

BENJAMIN, Walter. A obra de arte na época da sua possibilidade de reprodução técnica. In: BENJAMIN, Walter. A modernidade. Lisboa: Relógio de Água, 2006a, p. 207-241.

BENJAMIN, Walter. Pequena História da Fotografia. In: BENJAMIN, Walter. A modernidade. Lisboa: Relógio de Água, 2006b, p. 244-300.

BLEICHMAR, Daniela; SCHWARTZ, Vanessa. Visual History: the past in pictures. Representations, v. 145, I, 2019, p. 1-31.

BURKE, Peter. O que é história cultural? Rio de Janeiro: Jorge Zahar Ed., 2005. BURKE, Peter. Testemunha ocular: história e imagem. Bauru: EDUSC, 2004.

CÁCERES, Roberto Domínguez; GAYOL, Víctor. El imperio de lo visual. Imágenes, palabra y representación. In: CÁCERES, Roberto Domínguez; GAYOL, Víctor (coords.). El imperio de lo visual: imágenes, palabras, y representación. Zamora, Michoacán: EL Colégio de Michoacán, 2018, p. 11-26.

CERTEAU, Michel de. A operação historiográfica. In: CERTEAU, Michel de. A escrita da história. Rio de Janeiro: Forense Universitária, 2007. Pg. 56-108. 
CEZAR, Temístocles. Sob o firmamento da história: o "mito" do texto como representação objetiva do passado. In: FÉLIX, Loiva Otero; ELMIR, Cláudio (orgs.). Mitos e heróis: construção de imaginários. Porto Alegre: Ed. Universidade/ UFRGS, 1998.

DIDI-HUBERMAN, Georges. Diante do tempo: História de Arte e anacronismos das imagens. Lisboa: Orfeu Negro, 2017.

DUBOIS, Philippe. Da verossimilhança ao índice. In: DUBOIS, Philippe. 0 ato fotográfico e outros ensaios. Campinas: Papirus, 1993. Pg. 23-56.

FELDMAN, Allen. Formations of Violence: The Narrative of the Body and Political Terror in Northern Ireland. Chicago: University of Chicago Press, 1991.

GINZBURG, Carlo. "Seu país precisa de você": Um estudo de caso em iconografia política. In: GINZBURG, Carlo. Medo reverência, terror: Quatro ensaios de iconografia política. São Paulo: Companhia das Letras, 2014, p. 63-100.

GOMBRICH, E.H. Art and Illusion: A Study in the Psychology of Pictorial Presentation. Londres: Phaidon, 1968.

HARTOG, François; REVEL, Jacques. Note de conjucture historiographique. In: HARTOG, François; REVEL, Jacques (sous la direction). Les usages politiques du passe. Paris: EHEES, 2001. Pg. 13-24.

HARTOG, François. Disputas a respeito da narrativa. In: HARTOG, François. Evidência da história: o que os historiadores veem. Belo Horizonte: Autentica editora, 2011, p. 173-184.

HERF, Jeffrey. Reactionary modernism: Technology, culture, and politics in Weimar and the Third Reich. Cambridge University Press, 1984.

IGGERS, Georg. Historiography in the twentieth century: from scientific objectivity to the postmodern challenge. Middletown: Wesleyan University Press, 2005.

JORDANOVA, Ludmilla. The Look of the Past: Visual and Material Evidence in Historical Practice. Cambridge: Cambridge University Press, 2012.

JÚNIOR, Francisco das Chagas Fernandes Santigo. A virada e a imagem: história teórica do pictorial/iconic/visual turn e suas implicações para as humanidades. In: Anais Do Museu Paulista. São Paulo, Nova Série, vol. 27, 2019, p. 1-51. 
KANT, Immanuel. Crítica da razão pura. São Paulo: Nova Cultura, 2005. (Coleção Os Pensadores)

KOSELLECK, Reinhart. Futuro passado: contribuição à semântica dos tempos históricos. Rio de Janeiro: Contraponto, PUC-Rio, 2006.

KRACAUER, Siegfried. Fotografia. In: TRACHTENBERG, Alan (org.). Ensaios sobre Fotografia de Niépce a Krauss. Lisboa: Orfeu Negro, 2013, 267-294.

MALERBA, Jurandir. História \& narrativa: a ciência e a arte da escrita histórica. Petrópolis: Vozes, 2016.

MALERBA, Jurandir. O que narram os historiadores? Para uma genealogia da questão narrativa em História. In: MALERBA, Jurandir. Notas à margem: teoria e crítica historiográfica. Serra: Editora Milfontes, 2018. Pg. 183-208.

MENESES, Ulpiano. Fontes visuais, cultura visual, história visual. Balanço provisório, propostas cautelares. Revista Brasileira de História, São Paulo, v. 23, n. 45. 2003.

MENESES, Ulpiano. Rumo a uma história visual. In: MARTINS, J. S.; ECKERT, C.; NOVAES, S.C. (orgs.) O imaginário nas ciências sociais. Bauru: EDUSC, 2005. Pg. 33-56.

MENESES, Ulpiano. História e imagem: iconografia/iconologia e além. In: CARDOSO, Ciro; VAINFAS, Ronaldo (orgs.). Novos domínios da história. Rio de Janeiro: Elsevier, 2012. Pg. 243-262.

MITCHELL, W.J.T. Iconologie, Image, Texte, Ideologie. Paris: Les Praires Ordinaires, 2009.

MITCHELL, W.J.T. Picture Theory. Chicago: University of Chicago Press, 1994.

MONTEIRO, Charles. Construindo a história da cidade através de imagens. In: PESAVENTO, Sandra; ROSSINI, Miriam; SANTOS, Nádia. Narrativas, imagens e práticas sociais: percursos em história cultural. Porto Alegre: Asterisco, 2008. Pg. 148-171.

MONTEIRO, Charles. História, fotografia e cidade: reflexões teóricometodológicas sobre o campo de pesquisa. Métis: história \& cultura, v. 5, n. 9, jan/jun. 2006.

MOSSE, G. L. The Nationalization of the Masses: Political Symbolism and Mass 
Movements in Germany from the Napoleonic Wars through the Third Reich. Ithaca/Londres: Cornell University Press, 1975.

NOIRET, Serge. História pública digital. Liinc em Revista, Rio de Janeiro, v. 11, n. 1, maio de 2015 .

PANOFSKY, Erwin. Meaning in Visual Arts. Nova York: Doubleday, 1955.

RIBALTA, Jorge (ed.). Public Photographic Spaces: Propaganda Exhibitions from "Pressa” to “The Family of Man”, 1928-55. Barcelona: MAC-BA, 2010.

RICOEUR, Paul. Tempo e narrativa: a intriga e a narrativa histórica. Campinas: Papirus, 1995. Vol. 1.

RICOEUR, Paul. Mundo do texto e mundo do leitor. In: RICOEUR, Paul. Tempo e narrativa: O tempo narrado. Campinas: Papirus, 1995. Vol. 3. Pg. 273-314.

RÜSEN, Jörn. A constituição narrativa do sentido histórico. In: RÜSEN, Jörn. Razão histórica: teoria da história: fundamentos da ciência histórica. Brasília: Editora Universidade de Brasília, 2001. Pg. 149-174.

SILVEIRA, Pedro Telles. História, técnica e novas mídias: reflexões sobre a história na era digital. Tese (Doutorado), Porto Alegre: UFRGS, 2018.

SKINNER, Quentin. “Ambrogio Lorenzetti's Buon Governo Frescoes: Two Old Questions, Two New Answers.” Journal of the Warburg and Courtauld Institutes, 62 (1999), p. 1-28.

SONTAG, Susan. Ensaios sobre a fotografia. Lisboa: Publicações Dom Quixote, 1986.

STANLEY, David J. Sobre lo visual em la historia. Revista Digital de Historia Iberoamericana, v. 2, n. 1, 2009.

STONE, Lawrence. O ressurgimento da narrativa: reflexões sobre uma nova velha história. In: NOVAIS, Fernando; SILVA, Rogerio. Nova história em perspectiva. São Paulo: Cosac Naify, 2011.

TAGG, John. El peso de la representación: ensayos sobre fotografías y historias. Barcelona: Editorial Gustavo Gili, SA, 1988.

TAGG, John. O “Curso" da Fotografia. In: TRACHTENBERG, Alan (org.). Ensaios sobre fotografia de Niépce a Krauss. Lisboa: Orfeu Negro, 2013, p. 355-385. 
WHITE, Hayden. "Historiography and Historiophoty”. The American Historical Review, 93 (5), Dez. 1988, p. 1193-1199.

WHITE, Hayden. A questão da narrativa na teoria histórica contemporânea. In: NOVAIS, Fernando; SILVA, Rogerio. Nova história em perspectiva. São Paulo: Cosac Naify, 2011, p. 439-483.

\section{Notas}

${ }^{1}$ Doutor em História pela Pontifícia Universidade Católica do Rio Grande do Sul (PUCRS) com estágio doutoral na Universidade Livre de Berlim (FU-Berlin). Pesquisador associado da Rede Latino-Americana SARS-CoV2, Poder e Sociedade, do Colégio Latino-Americano de Estudos Mundiais, FLACSO/Brasil.

${ }^{2}$ Professora do Departamento de História da Universidade do Minho e investigadora do Laboratório de Patrimônio, Paisagem e Território (LAB2PT) da Universidade do Minho, Grupo Space and Representation (SpaceR).

${ }^{3}$ Sobre esse tema ver: JÚNIOR, 2019.

${ }^{4}$ Sobre a constituição e o desenvolvimento do campo da história visual, cf. BLEICHMAR; SCHWARTZ, 2019; MENESES, 2003; 2005; JORDANOVA, 2012.

${ }^{5}$ Sobre os obstáculos ao trabalho com fontes visuais e audiovisuais, cf. BURKE, 2004; MENESES, 2005.

${ }^{6}$ White (1988) desenvolve o conceito de historiophoty. Seu significado é o de representação da história a partir de imagens visuais e do discurso fílmico em contraste com o a imagem verbal e o discurso escrito.

\section{${ }^{7}$ Cf. SKINNER, 1999; GINZBURG, 2014; BELTING, 2017.}

${ }^{8}$ Note-se que Ricoeur (1995), partindo da análise da obra de Fernand Braudel, não deixa de afirmar que a história estrutural ou de longa duração é uma narrativa. Isto é, dispõe de uma intriga e de personagens, na esteira da concepção de narrativa de Stone. Este período da historiografia centrado no modelo dominantemente francês é denominado por Iggers (2005) de the middle phase: the challenge of social sciences, o período em que as ciências sociais nortearam a historiografia.

${ }^{9}$ Para Cezar (1998), essa mudança na historiografia abriu espaço para redimensionar e teorizar a própria escrita do historiador, vista a partir de então não mais como um ornamento, mas como forma que constrói conteúdo, de modo que o conteúdo do discurso histórico é indistinguível de sua forma. Ao teorizar-se a escrita do historiador, percebeuse a historiografia como uma narrativa que possui elementos retóricos, normas, códigos, subjetividade e (o que estranhou e contrariou muitos historiadores) ficção.

${ }^{10}$ White (2011) aponta concretamente os filósofos W. H Walsh, Patrick Gardiner, William H. Dray, W. B. Gallie, Morton White, Arthur Danto e Louis Mink.

${ }^{11}$ Sobre o conceito mundo do texto, cf. RICOEUR (1995, vol. 3).

${ }^{12}$ Acrescentando-se ao argumento de Rüsen, que para Hartog e Revel (2001) os 
historiadores, ao criarem narrativas sobre o passado, encontram-se na primeira linha de algumas das principais construções sobre o passado, pois produzem versões socialmente autorizadas desse mesmo passado. Assim, a historiografia faz circular representações, argumentações, todo um repertório de signos e formas que, através da leitura dos textos historiográficos, são incorporados na cultura e nos dispositivos identitários. Assim, não se trata somente do confronto entre narrativas historiográficas, onde cada uma busca fazer prevalecer a sua anterioridade, a sua legitimidade, os seus valores. Tratase também de narrativas e argumentações que mobilizam frequentemente as mesmas fontes e que as interpretam em termos divergentes ou contrários e que mutuamente se contestam e se negam.

${ }^{13}$ Rüsen (2001) afirma ainda que o sentido histórico requer três condições: a) formalmente: a estrutura de uma história, b) materialmente: a experiência do passado e c) funcionalmente: a orientação da vida humana prática por meio de representações da passagem do tempo.

${ }^{14}$ Estas reflexões foram potenciadas no âmbito do projeto de investigação e da proposta expositiva "O tom da Terra: constelações de memória colonial a partir do Arquivo Fotográfico da Diamang”, recalendarizada para abril-maio de 2021, em razão da pandemia de Covid-19. A iniciativa expositiva consubstancia uma proposta de interceção entre a História Colonial e a Arte Contemporânea Colonial e Pós-Colonial sob o horizonte dos estratos do tempo. $\mathrm{O}$ arquivo contempla mais de 25 mil imagens fotográficas maioritariamente de autoria de técnicos, sem formação especializada de base. Contrariando a suspeição inicial, em razão do contexto de produção do arquivo fotográfico da empresa colonial em estudo, o espólio contempla imagens de uma grande qualidade que escapam aos parâmetros propagandísticos e contratuais que estão na base da sua criação. A equipa multidisciplinar do projeto expositivo integra Duarte Belo (curador fotografia), Patrícia Leal (curadora artística), Miguel Duarte Bandeira, Maria Manuel Oliveira (consultora) e Fátima Moura Ferreira (responsável pela coordenação científica do programa).

${ }^{15}$ Figuras 1 e 2: fotografias nos. K-97_PT_MNS_AFD_153 e L-64_PT_MNS_AFD_153, sem data. Arquivo Fotográfico da Empresa de Diamantes de Angola, Diamang, Museu Nogueira da Silva-Universidade do Minho, cedidas no âmbito do projeto de investigação "Mapeamento e sentidos críticos do Arquivo Fotográfico da Companhia de Diamantes de Angola (Diamang): territórios, comunidades e memórias", Laboratório de Paisagens, Património e Território (Lab2PT), Grupo de investigação Space and Representation (SpaceR). Projeto sediado no Lab2PT- AUR/04509 com o apoio financeiro da FCT/ MCTES através de fundos nacionais (PIDDAC) e o cofinanciamento do Fundo Europeu de Desenvolvimento Regional (FEDER), ref ${ }^{a}$ POCI-01-0145-FEDER-007528, no âmbito do novo acordo de parceria PT2020 através do COMPETE 2020 - Programa Operacional Competitividade e Internacionalização (POCI). 